\title{
Leaching Behavior of Gold and Silver from Concentrated Sulfide Ore Using Ammonium Thiosulfate
}

\author{
Mooki Bae ${ }^{1,2}$, Sookyung Kim ${ }^{1,2, *}$, Jeongsoo Sohn ${ }^{2}$, Donghyo Yang ${ }^{2}$ and Hyunju Lee ${ }^{2, *}$ \\ 1 Resources Recycling, University of Science and Technology (UST), 217, Gajeong-ro, Yuseong-gu, \\ Daejeon 34113, Korea; muki.bae@kigam.re.kr \\ 2 Mineral Resources Research Division, Korea Institute of Geoscience and Mineral Resources (KIGAM), \\ 124 Gwahak-ro, Yuseong-gu, Daejeon 34132, Korea; jss@kigam.re.kr (J.S.); ydh@kigam.re.kr (D.Y.) \\ * Correspondence: skkim@kigam.re.kr (S.K.); hlee@kigam.re.kr (H.L.); \\ Tel.: +82-42-868-3020 (S.K.); +82-42-868-3151 (H.L.)
}

Received: 24 June 2020; Accepted: 29 July 2020; Published: 1 August 2020

\begin{abstract}
Ammonium thiosulfate is an alternative lixiviant for the hydrometallurgical treatment of sulfide gold ores. The present study is primarily focused on ammonium thiosulfate leaching of gold $(\mathrm{Au})$ and silver (Ag) from the sulfide ore (Sunshin mine in Korea). The main chemical composition of the concentrate was $\mathrm{Au}(84 \mathrm{ppm}), \mathrm{Ag}$ (852 ppm), Fe (18.9\%), Si (23.2\%), and S (21.1\%). The effects of various parameters on the process, such as leaching time $(1-4 \mathrm{~h})$, ammonium thiosulfate concentration (0.05-0.5 M), copper sulfate $\left(\mathrm{CuSO}_{4}\right)$, concentration $(0.05-0.25 \mathrm{M})$, solid to liquid ratio (0.2-0.5), and reaction temperature $\left(40-60^{\circ} \mathrm{C}\right)$ were systematically examined. Optimum Au leaching efficiency (>99\%) was obtained under the following leaching conditions: $0.5 \mathrm{M}$ ammonium thiosulfate with $0.05 \mathrm{M} \mathrm{CuSO}_{4}$ concentration, $0.2 \mathrm{~S} / \mathrm{L}$ ratio at $60{ }^{\circ} \mathrm{C}$ for $2 \mathrm{~h}$. The results indicate that the behavior of $\mathrm{Ag}$ was similar to that of Au. Almost complete dissolution of Ag occurred under following leaching conditions: $0.5 \mathrm{M}$ ammonium thiosulfate with $0.05 \mathrm{M} \mathrm{CuSO}_{4}$ concentration at $60{ }^{\circ} \mathrm{C}$ for $4 \mathrm{~h}$. This study would be useful in understanding the eco-friendly leaching systems of Au and Ag during the hydrometallurgical process of sulfide gold ore.
\end{abstract}

Keywords: concentrated sulfide ore; ammonium thiosulfate; copper sulfate; leaching; gold; silver

\section{Introduction}

For over 100 years, cyanide has been the most common leaching reagent for gold $(\mathrm{Au})$ recovery from ores and concentrates. Although cyanide has advantages including high Au recoveries, robustness, and relatively low costs, it is highly toxic and thus harmful to human health and the environment $[1,2]$. Various alternative lixiviants, such as halide, thiourea, and ammonium thiosulfate, have been extensively researched in the last few years [1]. Among them, ammonium thiosulfate, as an alternative to cyanide, has received much attention recently for a relatively cheap and nontoxic reagent solution [3].

In the 1990s, few researchers conducted Au leaching studies using ammonium thiosulfate with cupric ions acting as an oxidant [4-7]. Several studies to recover Au using ammoniacal thiosulfate have been reported in the past [8-12]. Senanayake explained the leaching behavior of Au by $\mathrm{Cu}$ (II) in ammoniacal thiosulfate solutions in the presence of additives $[8,9]$. The chemistry of the ammonia-thiosulfate-copper system is complex due to the simultaneous presence of complexing ligands such as ammonia and thiosulfate, $\mathrm{Cu}(\mathrm{II})-\mathrm{Cu}(\mathrm{I})$ redox couples in a solution. Hence, the practical application also requires consideration of the oxidation and stability of various sulfur species [13]. Aylmore and Muir conducted a thermodynamic analysis to provide a range of $\mathrm{pH}$ and Eh conditions for reagent concentrations [13]. In addition, the thiosulfate leaching process for Au extraction has 
been investigated in terms of leaching mechanism and kinetics [14-17]. Lampinen et al. investigated the ammoniacal thiosulfate leaching of pressure oxidized sulfide gold concentrate [18]. As a result, the highest $\mathrm{Au}$ extraction (89\%) was achieved in $6 \mathrm{~h}$ with the following leaching solutions: $0.2 \mathrm{M}$ thiosulfate concentration, $0.2 \mathrm{M}$ ammonia $\left(\mathrm{NH}_{3}\right), 0.1 \mathrm{~g} / \mathrm{L} \mathrm{Cu}$ [18].

In the case of silver $(\mathrm{Ag})$, several studies of leaching behavior have also been carried out by applying thiosulfate [19-21]. Ficeriova et al. investigated the mechanical activation and mechanochemical pretreatment step for thiosulfate leaching of $\mathrm{Ag}$, $\mathrm{Au}$, and bismuth (Bi) from sulfide concentrate [19]. It was possible to achieve more than $90 \%$ recovery of the examined metals. Alonso-Gómez and Lapidus carried out thermodynamic analyses for the different compositions of the leaching solution to determine their ability to extract $\mathrm{Ag}$, lead $(\mathrm{Pb})$, and $\mathrm{Au}$ [20]. Ayata and Yildiran suggested optimized conditions for the extraction of selective Ag from Ag sulfide concentrates by thiosulfate leaching [21].

The application of thiosulfate leaching behavior for Au recovery depends on the associated minerals. Pyrite, chalcopyrite, chalcocite, bornite, pyrrhotite, and arsenopyrite are the main sulfide minerals responsible for locking Au in refractory sulfide gold ores [22]. The leaching behavior of these minerals could play an important role in the thiosulfate leaching of Au sulfide ores [22]. Few researchers have studied the effect of associated minerals on Au leaching [10,23]. However, the composition of precious metals (including $\mathrm{Au}$ and $\mathrm{Ag}$ ) and base metals is highly dependent on the sulfide ores, and hence their properties are also different. Thus, it becomes necessary to study the leaching behavior of such sulfide ores.

The aim of the present study is to develop ammonium thiosulfate leaching of Au and Ag from the sulfide ore (Sunshin mine in Korea). This study is mainly focused on the leaching behavior of Au and $\mathrm{Ag}$ with respect to changes in ammonium thiosulfate and copper sulfate $\left(\mathrm{CuSO}_{4}\right)$ concentrations. The parameters studied for the optimization of the process conditions were ammonium thiosulfate $(0.05-0.5 \mathrm{M})$, reaction time $(1-4 \mathrm{~h})$, reaction temperature $\left(40-60^{\circ} \mathrm{C}\right)$, solid to liquid ratio $(0.2-0.5)$, and $\mathrm{CuSO}_{4}$ concentration $(0.05-0.25 \mathrm{M})$.

\section{Materials and Methods}

\subsection{Materials}

The gold ore sample was supplied from Sunshin Mine (or Moisan Mine), which in Haenam epithermal gold mineralized area, Korea. Those ore was concentrated by crushing, ball mill, hydro-cyclone, and flotation. Samples were then collected for chemical analysis and size distribution characterization. Quantitative analysis by XRD was carried out by estimation of XRD with SRM (Standard Reference Material) using PDXL (Ver. 2.8.4.0., Rigaku Ltd., Akishima, Tokyo, Japan) to determine the mineralogy of the concentrated sulfide ore, as shown in Figure 1. It indicates that the ore contains the quartz: $40.5 \%$, pyrite: $40.1 \%$, and muscovite: $19.3 \%$.

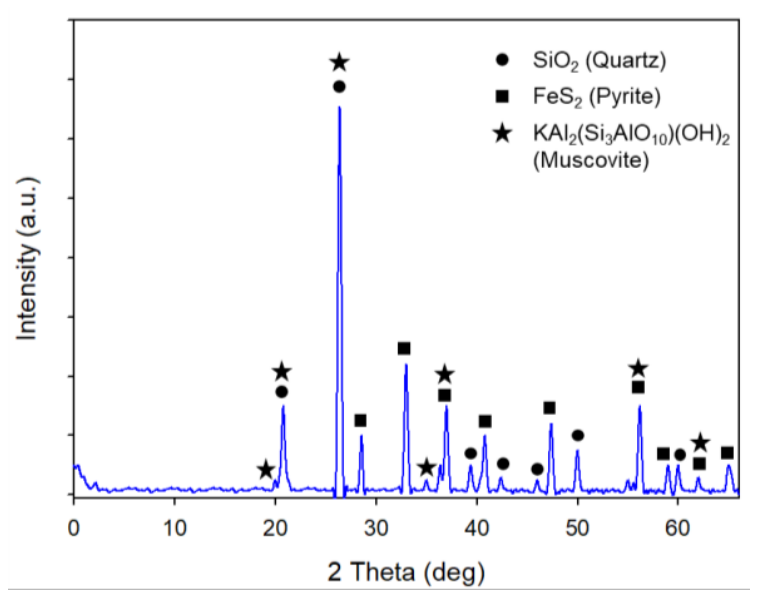

Figure 1. XRD pattern of concentrated sulfide gold ore. 
The particle size distribution of the gold concentrates by a particle size analyzer (Mastersizer 2000, Malvern Panalytical Ltd., Malvern, UK) is seen in Figure 2. The particle size analysis showed that the D50 value of the concentrated gold ore after flotation was $45.3 \mu \mathrm{m}$. Table 1 shows the results of chemical analysis of the ore. Au and Ag content was determined as 84 ppm and 852 ppm, respectively, by fire-assay, and other elements were determined by acid digestion followed by atomic absorption spectroscopy (A400 model, Perkin Elmer Ltd., Waltham, MA, USA). Sulfur content determined by a Carbon/Sulfur Determinator (CS230 Series, LECO Ltd., St. Joseph, MI, USA) was $21.1 \mathrm{wt.} \%$.

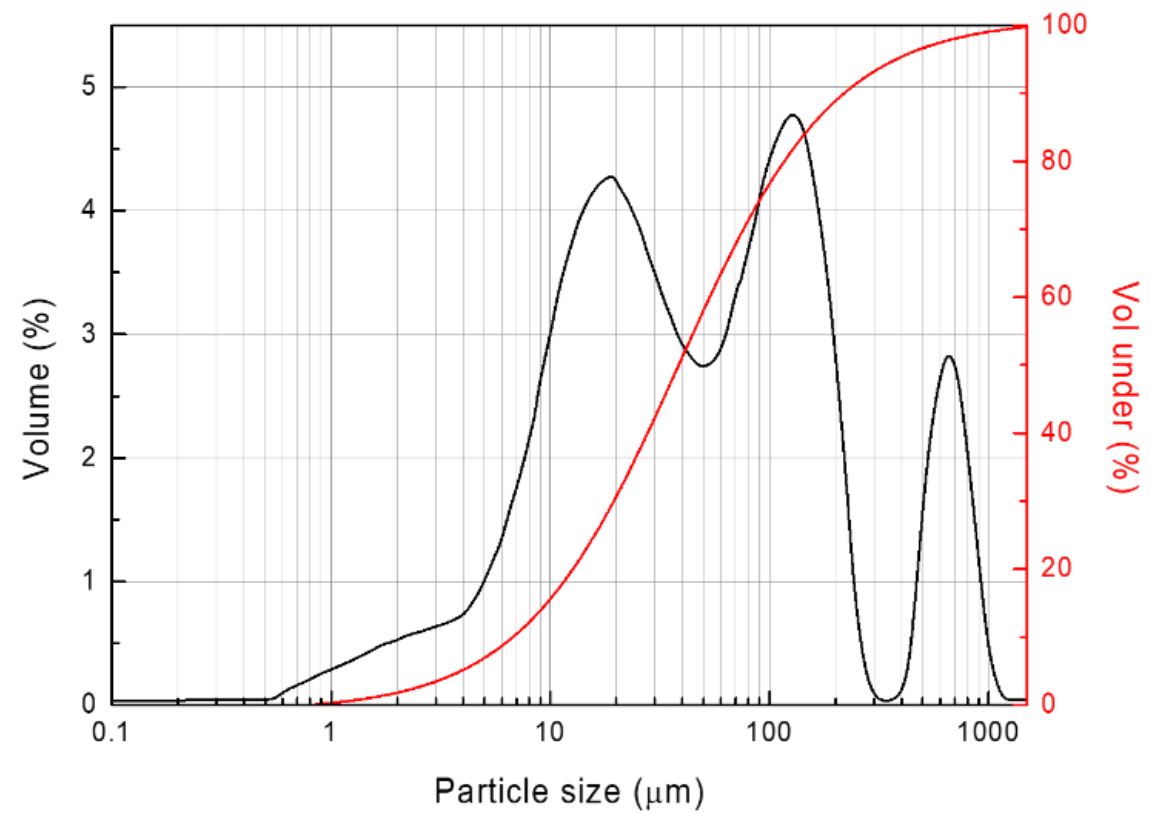

Figure 2. Particle size distribution of concentrated sulfide gold ore.

Table 1. The chemical analysis of concentrated sulfide ore $\left(\mathrm{Au}^{*}, \mathrm{Ag}^{*}: \mathrm{ppm}\right)$.

\begin{tabular}{ccccccccccccc}
\hline Element & $\mathbf{A u}^{*}$ & $\mathbf{A g}^{*}$ & $\mathbf{A l}$ & $\mathbf{F e}$ & $\mathbf{M g}$ & $\mathbf{N a}$ & $\mathbf{P b}$ & $\mathbf{C u}$ & $\mathbf{Z n}$ & $\mathbf{T i}$ & $\mathbf{S i}$ & $\mathbf{S}$ \\
\hline $\begin{array}{c}\text { Contents } \\
\text { (wt. } \%)\end{array}$ & 84.0 & 852 & 2.42 & 18.9 & 0.0820 & 0.160 & 0.270 & 0.380 & 0.440 & 0.170 & 23.2 & 21.1 \\
\hline
\end{tabular}

For the leaching experiment, ammonium thiosulfate $\left(\left(\mathrm{NH}_{4}\right)_{2} \mathrm{~S}_{2} \mathrm{O}_{3}\right)$, Copper (II) sulfate $\left(\mathrm{CuSO}_{4}\right)$, and sodium hydroxide $(\mathrm{NaOH})$ were used as the reagents. A pH meter (Orion 3-Star Benchtop, Thermo Scientific Ltd.) was used for the $\mathrm{pH}$ measurements of the leaching solutions.

\subsection{Methods}

The as-received sulfide ore was dried in an oven at $80^{\circ} \mathrm{C}$. For the thiosulfate leaching tests, the ammonium thiosulfate $(0.05-0.5 \mathrm{M})$ with $\mathrm{CuSO}_{4}(0.05-0.25 \mathrm{M})$ was dissolved in distilled water. Experiments were carried out in a $150 \mathrm{~mL}$ glass reactor located in a heating mantle equipped with a $\mathrm{pH}$ meter and mechanical stirrer. As soon as the temperature of the flask reached the set temperature, $30-75 \mathrm{~g}$ of the given ore (S/L ratios of $0.2,0.33$, and 0.5 ) were added to it. A stirrer with the rotational speed of $300 \mathrm{rpm}$ was used to mix the solution. Samples of the solution were withdrawn at different time intervals $(1-4 \mathrm{~h})$. After suitable dilution, $\mathrm{Au}$ and Ag contents were determined by AAS in combination with the fire assay method for analysis of residues in order to estimate the leaching efficiency. The leaching experiments were performed twice to minimize the sampling error. 


\section{Results and Discussion}

\subsection{Effect of Temperature on Au and Ag Leaching Efficiency}

For investigating the leaching behavior, the temperature variation was carried out from 40 to $60{ }^{\circ} \mathrm{C}$ for $1 \mathrm{~h}, 0.2 \mathrm{~S} / \mathrm{L}$ ratio, $\mathrm{pH} 9.5$ using $0.5 \mathrm{M}$ ammonium thiosulfate, and $0.05 \mathrm{M} \mathrm{CuSO}_{4}$.

The effect of temperature and time on $\mathrm{Au}$ and $\mathrm{Ag}$ leaching by ammonium thiosulfate solutions is shown in Figure 3. As shown in Figure 3a, the Au leaching efficiency increases with the increase in temperature in the range of $40{ }^{\circ} \mathrm{C}$ to $60{ }^{\circ} \mathrm{C}$, and $>99 \%$ leaching efficiency is reached at $60{ }^{\circ} \mathrm{C}$ after $2 \mathrm{~h}$. However, in case of $\mathrm{Ag}$ (Figure $3 \mathrm{~b}$ ), the leaching efficiency rapidly increased up to $1 \mathrm{~h}$ of reaction at all temperatures, and then gradually increased over next time intervals. The results of the present study indicate that, with leaching process conditions at $60^{\circ} \mathrm{C}$ for $4 \mathrm{~h}$, the $\mathrm{Au}$ and $\mathrm{Ag}$ were found to be almost dissolved. Contrary to our results, Abbruzzese et al. found that Au recovery decreases with increasing temperature from 25 to $60{ }^{\circ} \mathrm{C}$ [6]. They further suggested that the kinetics of cupric sulfide film formation is very high at $60^{\circ} \mathrm{C}$, which hinders Au dissolution [6]. However, in this study, no decrease in Au recovery was observed throughout the temperature range $\left(40\right.$ to $\left.60{ }^{\circ} \mathrm{C}\right)$. Based on the results obtained, the temperature of the leaching experiment was selected as $60^{\circ} \mathrm{C}$.
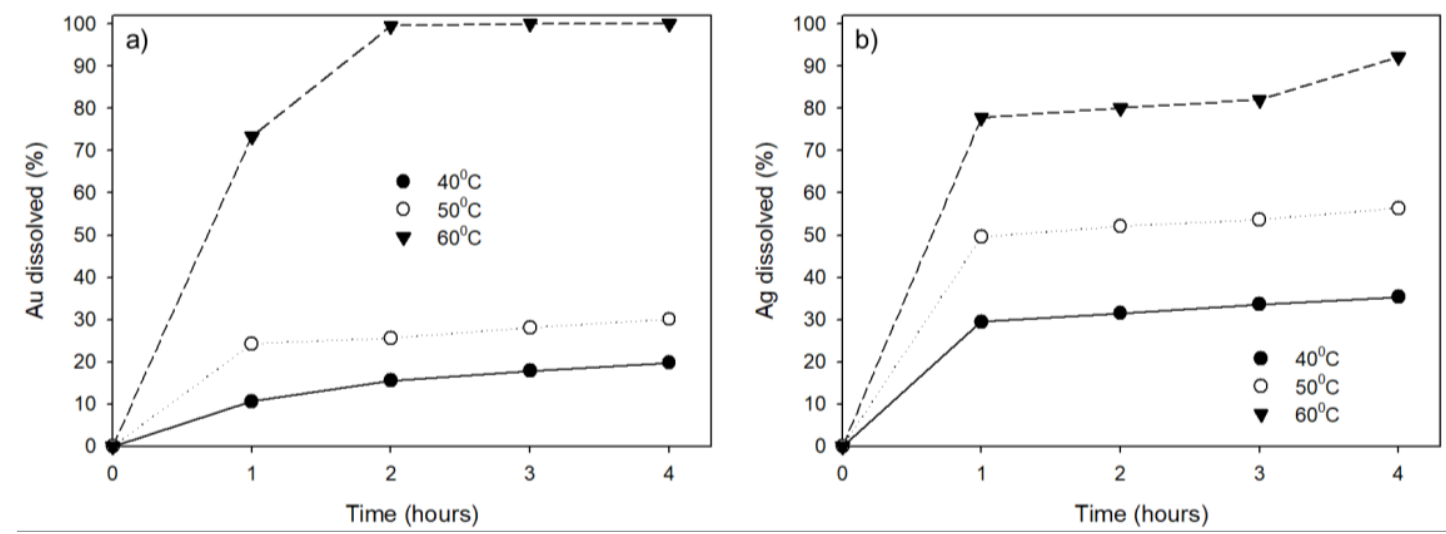

Figure 3. Effect temperature and time on metals leaching efficiency: (a) Au, (b) Ag. (Experimental conditions: $0.5 \mathrm{M}$ ammonium thiosulfate, $0.05 \mathrm{M} \mathrm{CuSO}_{4}, 0.2 \mathrm{~S} / \mathrm{L}$ ratio, $\mathrm{pH}$ 9.5).

\subsection{Effect of Ammonium Thiosulfate Concentration on Au and Ag Leaching Efficiency}

Figure 4 shows the effect of ammonium thiosulfate concentration (in the range of $0.05-0.5 \mathrm{M}$ ) on the leaching efficiency of $\mathrm{Au}$ and $\mathrm{Ag}$, as a function of time (from 1 to $4 \mathrm{~h}$ ) with $60{ }^{\circ} \mathrm{C}$ temperature, $0.2 \mathrm{~S} / \mathrm{L}$ ratio, and $0.05 \mathrm{M} \mathrm{CuSO}_{4}$ concentration. It is observed that the leaching efficiency of Au and $\mathrm{Ag}$ increases with increasing concentration of ammonium thiosulfate and the chemical reaction time. As shown in Figure $4 \mathrm{a}$, in the case of $\mathrm{Au}$, there was no leaching of $\mathrm{Au}$ for $0.05 \mathrm{M}$ concentration of ammonium thiosulfate until $3 \mathrm{~h}$. In contrast, as the ammonium thiosulfate concentration was increased from $0.4 \mathrm{M}$ to $0.5 \mathrm{M}$, Au dissolved gradually with increasing order, and, in particular, a leaching efficiency of $>99 \%$ was observed for $\mathrm{Au}$ at $0.5 \mathrm{M}$ ammonium thiosulfate for $2 \mathrm{~h}$. The leaching behavior of Ag was found to be similar to that of Au. Ag was not leached for 0.05 to $0.1 \mathrm{M}$ concentrations of ammonium thiosulfate (Figure 4b); however, Ag was almost completely dissolved with $0.5 \mathrm{M}$ concentration of ammonium thiosulfate for $4 \mathrm{~h}$. This clearly indicates that the leaching efficiency of both $\mathrm{Au}$ and $\mathrm{Ag}$ increased with the increasing concentration of ammonium thiosulfate, and at least $0.4 \mathrm{M}$ or more of ammonium thiosulfate is required to leach $\mathrm{Au}$ and $\mathrm{Ag}$ in this system. In this study, $\mathrm{Au}$ and Ag were almost completely dissolved by ammonium thiosulfate. It is probably due to not trapping $\mathrm{Au}$ and Ag into the pyrite or quartz. 

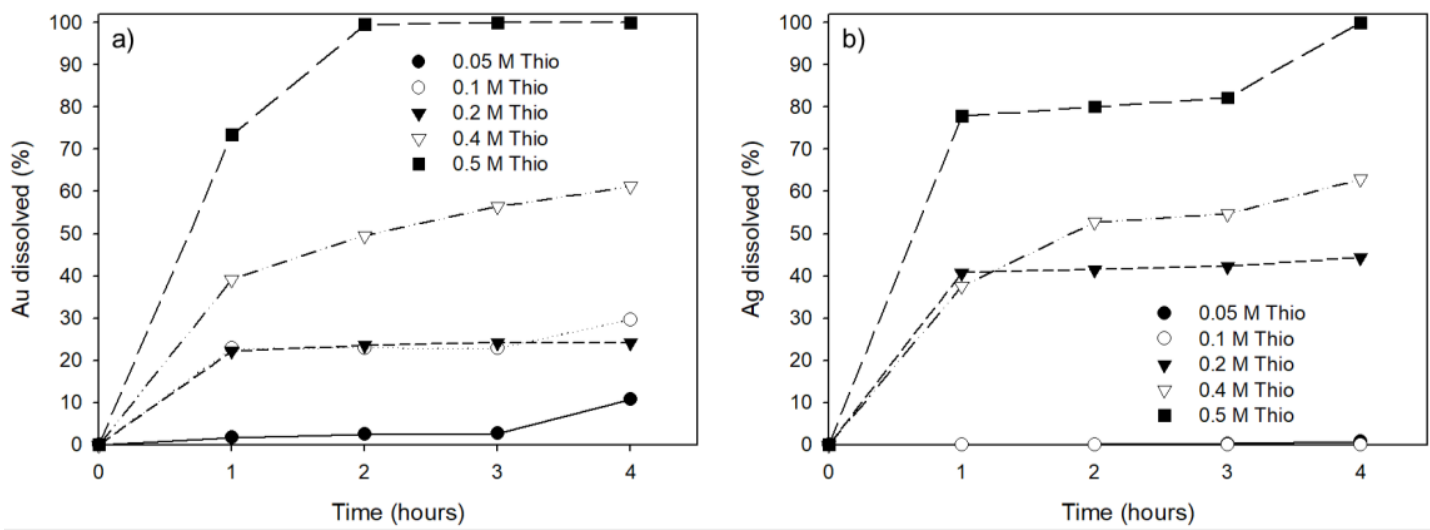

Figure 4. Effect of ammonium thiosulfate concentration on metals leaching efficiency: (a) Au, (b) Ag. (Experimental conditions: $0.05 \mathrm{M} \mathrm{CuSO}_{4}, 0.2 \mathrm{~S} / \mathrm{L}$ ratio, $\mathrm{pH} 9.5,60^{\circ} \mathrm{C}$ ).

\subsection{Effect of Copper Sulfate Concentration on Au and Ag Leaching Efficiency}

Figure 5 shows the leaching efficiency of $\mathrm{Au}$ and $\mathrm{Ag}$ with the variation in $\mathrm{CuSO}_{4}$ concentration. These studies were carried out at $60{ }^{\circ} \mathrm{C}$ temperature and $0.2 \mathrm{~S} / \mathrm{L}$ ratio using the $0.5 \mathrm{M}$ ammonium thiosulfate solution. As shown in Figure 5a, the leaching efficiency of Au during the first hour increased rapidly. At higher $\mathrm{Cu}$ ion concentrations (from $0.25 \mathrm{M}$ to $0.1 \mathrm{M}$ ), the leaching efficiency of $\mathrm{Au}$ reached up to $>99 \%$ in $1 \mathrm{~h}$. With $0.05 \mathrm{M} \mathrm{CuSO}_{4}$ concentration, the leaching efficiency of Au was increased from $73.4 \%$ to $>99 \%$ during the $1-2 \mathrm{~h}$ interval. In the case of $\mathrm{Ag}$ (Figure $5 \mathrm{~b}$ ), an increase in the leaching efficiency of $\mathrm{Ag}$ was observed, as the concentration of $\mathrm{CuSO}_{4}$ was increased from $0.05 \mathrm{M}$ to $0.25 \mathrm{M}$. From $0.15 \mathrm{M}$ to $0.25 \mathrm{M}$ of $\mathrm{Cu}$ ion concentrations, the leaching efficiency of $\mathrm{Ag}$ reached up to $>99 \%$ in the $1 \mathrm{~h}$. Similar to $\mathrm{Au}$, even for a small $\mathrm{CuSO}_{4}$ concentration $(0.05 \mathrm{M})$, almost $77.8 \% \mathrm{Ag}$ was leached in the $1 \mathrm{~h}$ and $>99 \% \mathrm{Ag}$ dissolution was found in $4 \mathrm{~h}$.
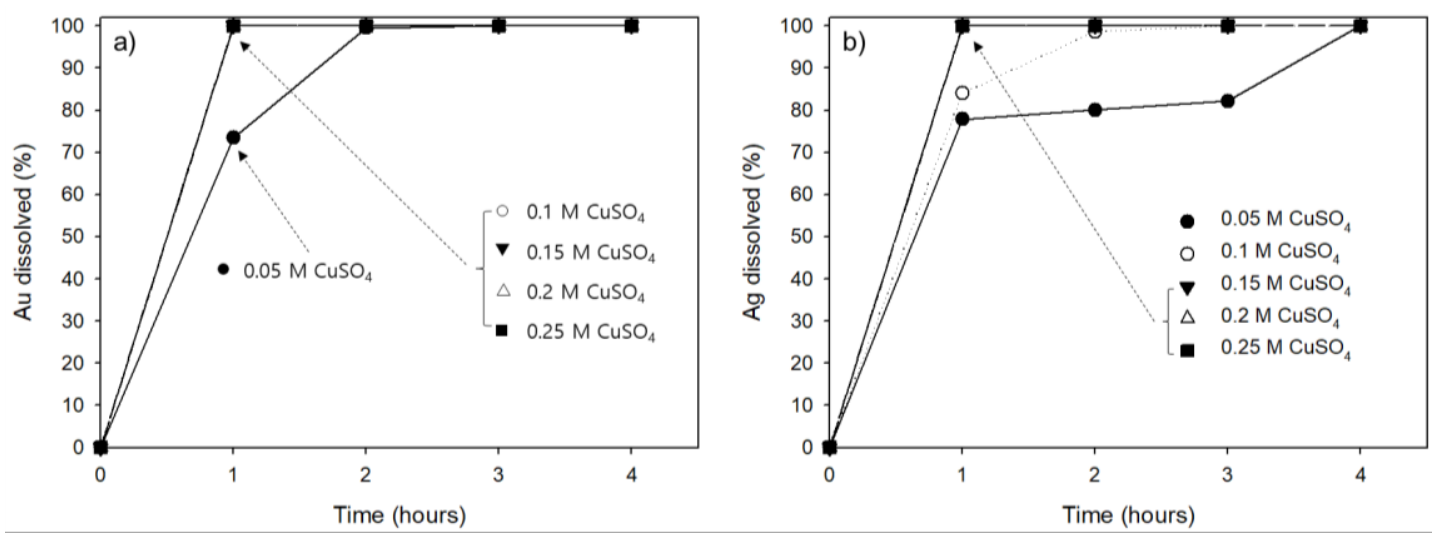

Figure 5. Effect of $\mathrm{CuSO}_{4}$ concentration on metals leaching efficiency: (a) Au, (b) Ag. (Experimental conditions: $0.5 \mathrm{M}$ ammonium thiosulfate, $0.2 \mathrm{~S} / \mathrm{L}$ ratio, $\mathrm{pH} 9.5,60^{\circ} \mathrm{C}$ ).

3.4. Correlation between the Concentration of Ammonium Thiosulfate and Copper Sulfate for Au and Ag Leaching

The three-dimensional plot has been analyzed to investigate the effect of concentrations of ammonium thiosulfate and $\mathrm{CuSO}_{4}$ on the leaching efficiency of Au and Ag. Figure 6 shows a 3D plot of the ammonium thiosulfate concentration, $\mathrm{CuSO}_{4}$ concentration, and leaching efficiency of $\mathrm{Au}$ and $\mathrm{Ag}$. The $z$-value represents the leaching efficiency for 1 and $4 \mathrm{~h}$, respectively, $x$ is the $\mathrm{CuSO}_{4}$ concentration, and $y$ is the ammonium thiosulfate concentration. As visible in Figure 6, the leaching efficiency of $\mathrm{Au}$ and $\mathrm{Ag}$ increases with increase in the concentrations of ammonium thiosulfate and $\mathrm{CuSO}_{4}$. For the initial $1 \mathrm{~h}$ leaching behavior of Au (Figure 6a), the leaching efficiency of the Au was more affected 
by the change in $\mathrm{CuSO}_{4}$ concentration than that of ammonium thiosulfate. However, the effect of ammonium thiosulfate concentration increased as the leaching time increased (Figure 6b). In the case of Ag (Figure 6c,d), it was observed that the leaching efficiency of the Ag was more affected by the change in ammonium thiosulfate concentration than that of $\mathrm{CuSO}_{4}$. Interestingly, the trend of $\mathrm{Au}$ and $\mathrm{Ag}$ leaching efficiency with $\mathrm{CuSO}_{4}$ and ammonium thiosulfate followed the plane graph with increasing leaching time (Figure $6 \mathrm{~b}, \mathrm{~d}$ ). The ideal plane graph was calculated using the given data, and the values are shown in Figure 6 . The $\mathrm{R}^{2}$ (coefficient of determination) values of the two graphs (Figure $6 \mathrm{~b}, \mathrm{~d}$ ) were found to be 0.9658 and 0.9688 , respectively, which were relatively consistent with the plane graphs.
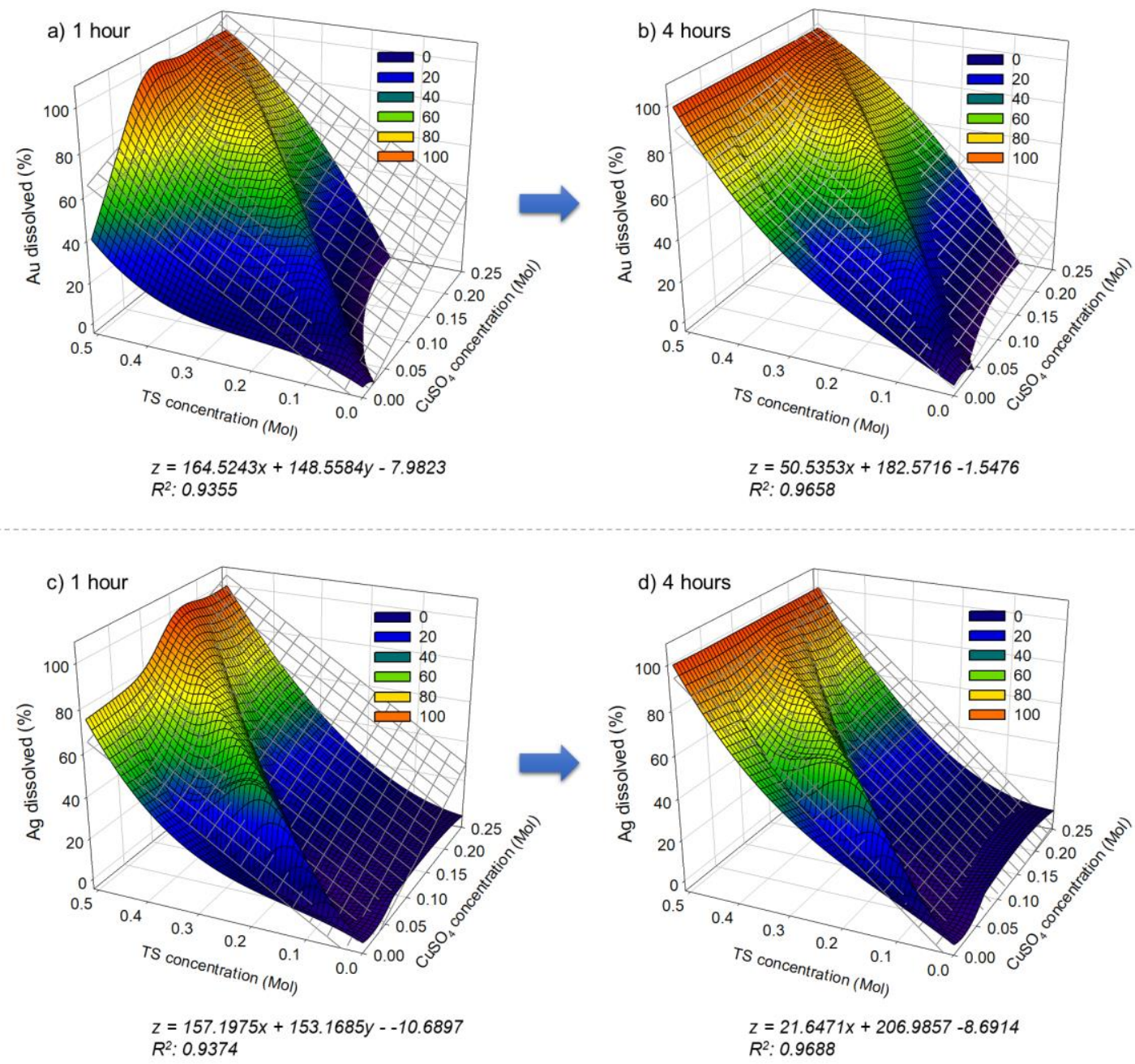

Figure 6. Correlation between the concentration of ammonium thiosulfate and $\mathrm{CuSO}_{4}$ on metals leaching efficiency: (a,b) $\mathrm{Au}$ and (c,d) Ag. (Experimental conditions: $0.2 \mathrm{~S} / \mathrm{L}$ ratio, $\mathrm{pH} 9.5,60^{\circ} \mathrm{C}$ ).

\subsection{Effect of $\mathrm{pH}$ on $\mathrm{Au}$ and $\mathrm{Ag}$ Leaching Efficiency}

For the effective dissolution of $\mathrm{Au}$ and $\mathrm{Ag}$, leaching experiments were conducted under the $\mathrm{pH}$ variation (from 7.0 to 9.5), with experimental conditions of $0.2 \mathrm{~S} / \mathrm{L}$ ratio, $0.5 \mathrm{M}$ ammonium thiosulfate concentration, $0.05 \mathrm{M} \mathrm{CuSO}_{4}$ concentration, at $60{ }^{\circ} \mathrm{C}$ temperature for $4 \mathrm{~h}$. As shown in Figure 7, the leaching efficiency of both $\mathrm{Au}$ and $\mathrm{Ag}$ increased with increasing $\mathrm{pH}$ value. The leaching efficiency of $\mathrm{Au}$ increased from approximately 65\% to 99\%, whereas leaching efficiency of Ag increased from approximately $55 \%$ to $99 \%$, for the corresponding $\mathrm{pH}$ range of 7 to 9.5 . The $\mathrm{pH}$ of the ammonium thiosulfate leaching process is generally maintained between 9 and 10 such that the presence of ammonia is ensured in order to dissolve $\mathrm{Cu}$ as a $\mathrm{Cu}(\mathrm{II})$-ammonia complex. Molleman and Dreisinger 
reported that ammonium thiosulfate leaching for Au recovery should preferably be performed at a $\mathrm{pH}$ of 9-10 [24]. As a result, the $\mathrm{pH}$ of 9.5 was found suitable for $\mathrm{Au}$ and Ag leaching in the present study.

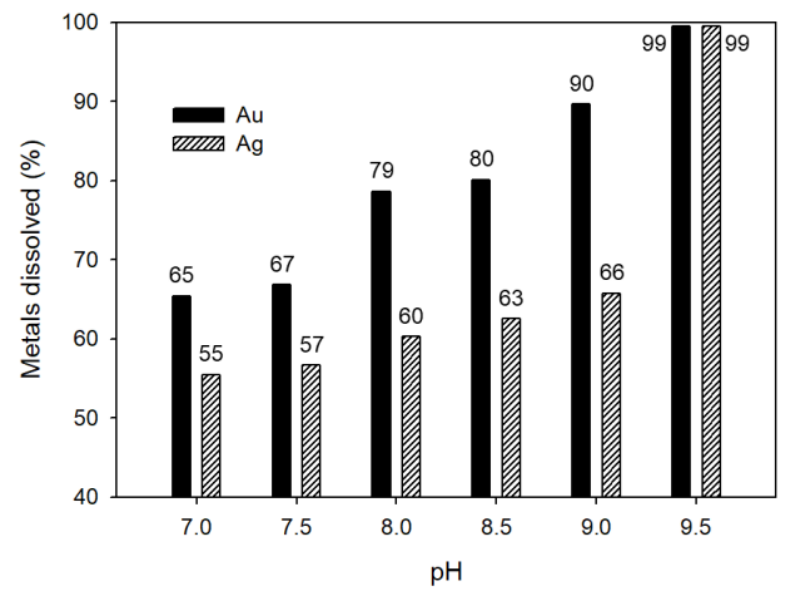

Figure 7. Effect of $\mathrm{pH}$ on $\mathrm{Au}$ and $\mathrm{Ag}$ leaching efficiency. (Experimental conditions: $0.5 \mathrm{M}$ ammonium thiosulfate, $0.05 \mathrm{M} \mathrm{CuSO}_{4}, 0.2 \mathrm{~S} / \mathrm{L}$ ratio, $60{ }^{\circ} \mathrm{C}$ ).

\subsection{Effect of Solid/Liquid ratio on Au and Ag Leaching Efficiency}

Leaching is a solid-liquid reaction, wherein the two phases are in intimate contact; the solute can diffuse from the solid to the liquid phase, which causes a separation of the components originally present in the solid. In addition, pulp density is a key factor influencing mass transfer kinetics in $\mathrm{Au}$ metallurgical operation [25].

Experiments were carried out at various $\mathrm{S} / \mathrm{L}$ ratios $(0.2,0.33$, and 0.5$)$ using $0.5 \mathrm{M}$ ammonium thiosulfate concentration with $0.05 \mathrm{M} \mathrm{CuSO}_{4}$ concentration. These experiments carried out at $60^{\circ} \mathrm{C}$ temperature and leaching periods ranging from 1 to $4 \mathrm{~h}$ are presented in Figure 8. The leaching efficiency of $\mathrm{Au}$ (Figure 8a) has been significantly decreased from $>99 \%$ to $24 \%$ when the S/L ratio was increased from 0.2 to 0.5 for $4 \mathrm{~h}$. It can be observed that the lower $\mathrm{S} / \mathrm{L}$ ratio enhances the leaching efficiency of $\mathrm{Au}$, while, at higher $\mathrm{S} / \mathrm{L}$ ratios, it decreased, which can be attributed to the need for greater thiosulfate concentrations as the pulp density increases [26,27]. Navarro et al. reported that the maximum leaching efficiency of Au can be achieved by increasing the thiosulfate concentration when the pulp density is increased [26]. In case of $\mathrm{Au}$, the results suggest that a high leaching rate of $\mathrm{Au}$ at $60{ }^{\circ} \mathrm{C}$ and $0.2 \mathrm{~S} / \mathrm{L}$ ratio with preferred concentrations of ammonium thiosulfate $(0.5 \mathrm{M})$ and $\mathrm{CuSO}_{4}$ $(0.05 \mathrm{M})$ leads to high leaching efficiency. Unlike $\mathrm{Au}$, the leaching efficiency of Ag (Figure $8 \mathrm{~b}$ ) has been decreased from $>99 \%$ to $69 \%$ with an increase in the $\mathrm{S} / \mathrm{L}$ ratio from 0.2 to 0.5 for $4 \mathrm{~h}$. It was confirmed that $\mathrm{Au}$ is more sensitive to pulp density than $\mathrm{Ag}$ in terms of leaching efficiency.
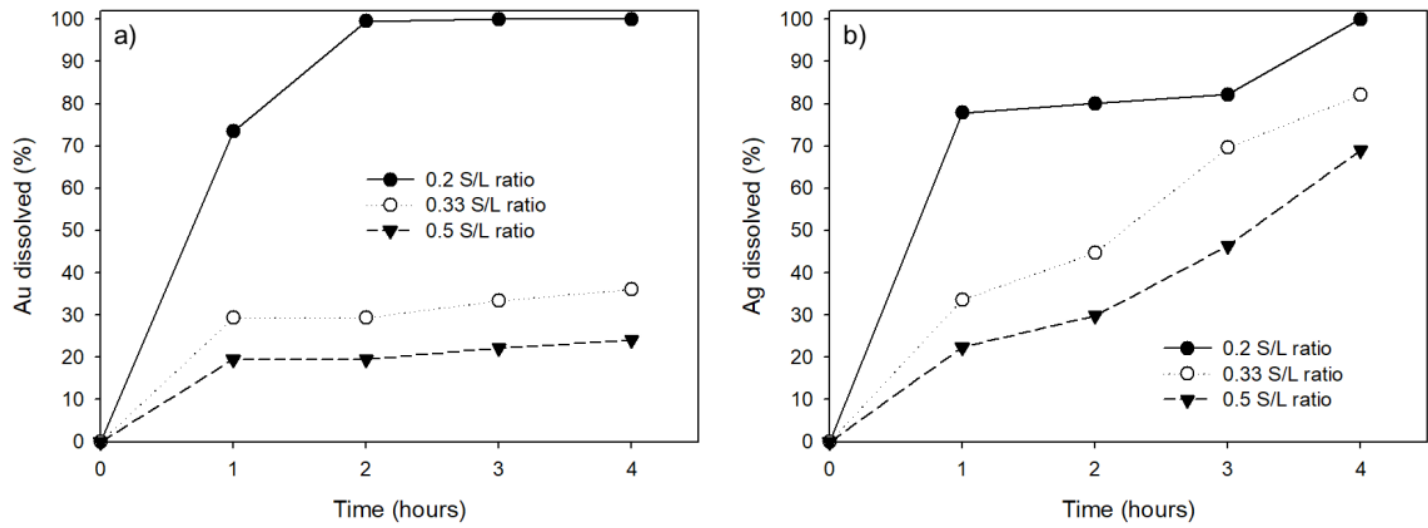

Figure 8. Effect of solid/liquid ratio for metals leaching efficiency: (a) Au, (b) Ag. (Experimental conditions: $0.5 \mathrm{M}$ ammonium thiosulfate, $0.05 \mathrm{M} \mathrm{CuSO}_{4}, \mathrm{pH}_{9.5}, 60^{\circ} \mathrm{C}$ ). 


\section{Conclusions}

In this study, the ammonium thiosulfate leaching process has been investigated for the recovery of $\mathrm{Au}$ and $\mathrm{Ag}$ from concentrated sulfide ore. In particular, the present study was mainly focused on the leaching behavior of $\mathrm{Au}$ and $\mathrm{Ag}$ with the ammonium thiosulfate and $\mathrm{CuSO}_{4}$ concentration changes. Improvements in the leaching efficiency of $\mathrm{Au}$ and $\mathrm{Ag}$ were found with the increase in concentrations of ammonium thiosulfate and $\mathrm{CuSO}_{4}$. Interestingly, the trend of leaching efficiency with $\mathrm{CuSO}_{4}$ and ammonium thiosulfate followed the plane graph. Furthermore, the temperature and $\mathrm{pH}$ of the leaching experiment were important factors in determining the leaching efficiency. Optimal leaching efficiency was obtained at $60{ }^{\circ} \mathrm{C}$ and $\mathrm{pH}$ 9.5. On the other hand, the leaching efficiency decreased to $24 \%$ for $\mathrm{Au}$ and $69 \%$ for $\mathrm{Ag}$ from $99 \%$, when the S/L ratio was increased from 0.2 to 0.5 for $4 \mathrm{~h}$. Based on obtained results, it was found that the leaching process for the recovery of Au and Ag can achieve $>99 \%$ efficiency with the following optimum leaching conditions: $0.5 \mathrm{M}$ ammonium thiosulfate, $0.05 \mathrm{M}$ $\mathrm{CuSO}_{4}$ concentration, $\mathrm{S} / \mathrm{L}$ ratio of 0.2 , temperature at $60^{\circ} \mathrm{C}$, and $\mathrm{pH}$ of 9.5 .

Author Contributions: Methodology, M.B. and S.K.; writing—original draft preparation, M.B. and H.L.; Project Administration and funding acquisition, J.S., D.Y and S.K.; data curation, M.B., J.S., and D.Y.; writing-review and editing, providing ideas, M.B., S.K., and H.L. All authors have read and agreed to the published version of the manuscript.

Funding: This research was funded by the R\&D Center for Valuable Recycling (Global-Top R\&BD Program), Ministry of Environment, Korea, project number 2016002250004.

Conflicts of Interest: The authors declare no conflicts of interest.

\section{References}

1. Hilson, G.; Monhemius, A.J. Alternatives to cyanide in the gold mining industry: What prospects for the future? J. Clean. Prod. 2006, 14, 1158-1167. [CrossRef]

2. Syed, S. Recovery of gold from secondary sources-A review. Hydrometallurgy 2012, 115-116, 30-51. [CrossRef]

3. Muir, D.M.; Aylmore, M.G. Thiosulphate as an alternative to cyanide for gold processing - issues and impediments. Miner. Process. Extr. Metall. 2004, 113, 2-12. [CrossRef]

4. Porvali, A.; Rintala, L.; Aromaa, J.; Kaartinen, T.; Forsen, O.; Lundstrom, M. Thiosulfate-copper-ammonia leaching of pure gold and pressure oxidized concentrate. Physicochem. Probl. Miner. Process. 2017. [CrossRef]

5. Langhans, J.W.; Lei, K.P.V.; Carnahan, T.G. Copper-catalyzed thiosulfate leaching of low-grade gold ores. Hydrometallurgy 1992, 29, 191-203. [CrossRef]

6. Abbruzzese, C.; Fornari, P.; Massidda, R.; Vegliò, F.; Ubaldini, S. Thiosulphate leaching for gold hydrometallurgy. Hydrometallurgy 1995, 39, 265-276. [CrossRef]

7. Zipperian, D.; Raghavan, S.; Wilson, J.P. Gold and silver extraction by ammoniacal thiosulfate leaching from a rhyolite ore. Hydrometallurgy 1988, 19, 361-375. [CrossRef]

8. Senanayake, G. Gold leaching by copper(II) in ammoniacal thiosulphate solutions in the presence of additives. Part I: A review of the effect of hard-soft and Lewis acid-base properties and interactions of ions. Hydrometallurgy 2012, 115-116, 1-20. [CrossRef]

9. Senanayake, G.; Zhang, X.M. Gold leaching by copper(II) in ammoniacal thiosulphate solutions in the presence of additives. Part II: Effect of residual $\mathrm{Cu}(\mathrm{II}), \mathrm{pH}$ and redox potentials on reactivity of colloidal gold. Hydrometallurgy 2012, 115-116, 21-29. [CrossRef]

10. Xu, B.; Kong, W.; Li, Q.; Yang, Y.; Jiang, T.; Liu, X. A Review of Thiosulfate Leaching of Gold: Focus on Thiosulfate Consumption and Gold Recovery from Pregnant Solution. Metals 2017, 7, 222. [CrossRef]

11. Xu, B.; Yang, Y.; Jiang, T.; Li, Q.; Zhang, X.; Wang, D. Improved thiosulfate leaching of a refractory gold concentrate calcine with additives. Hydrometallurgy 2015, 152, 214-222. [CrossRef]

12. Mahmoud, M.H.H.; Awad, H.M. Improved recovery of gold and silver from thiosulfate solution on activated carbon in presence of ammonium persulfate. Physicochem. Probl. Miner. Process. 2019. [CrossRef]

13. Aylmore, M.G.; Muir, D.M. Thermodynamic analysis of gold leaching by ammoniacal thiosulfate using Eh/pH and speciation diagrams. Min. Metall. Explor. 2001, 18, 221-227. [CrossRef] 
14. Senanayake, G. Analysis of reaction kinetics, speciation and mechanism of gold leaching and thiosulfate oxidation by ammoniacal copper(II) solutions. Hydrometallurgy 2004, 75, 55-75. [CrossRef]

15. Seisko, S.; Lampinen, M.; Aromaa, J.; Laari, A.; Koiranen, T.; Lundström, M. Kinetics and mechanisms of gold dissolution by ferric chloride leaching. Miner. Eng. 2018, 115, 131-141. [CrossRef]

16. Roldán-Contreras, E.; Salinas-Rodríguez, E.; Hernández-Ávila, J.; Cerecedo-Sáenz, E.; Rodríguez-Lugo, V.; Jeldres, R.I.; Toro, N. Leaching of Silver and Gold Contained in a Sedimentary Ore, Using Sodium Thiosulfate; A Preliminary Kinetic Study. Metals 2020, 10, 159. [CrossRef]

17. Birich, A.; Stopic, S.; Friedrich, B. Kinetic Investigation and Dissolution Behavior of Cyanide Alternative Gold Leaching Reagents. Sci. Rep. 2019, 9, 7191. [CrossRef]

18. Lampinen, M.; Laari, A.; Turunen, I. Ammoniacal thiosulfate leaching of pressure oxidized sulfide gold concentrate with low reagent consumption. Hydrometallurgy 2015, 151, 1-9. [CrossRef]

19. Ficeriová, J.; Baláž, P.; Leon Villachica, C. Thiosulfate leaching of silver, gold and bismuth from a complex sulfide concentrates. Hydrometallurgy 2005, 77, 35-39. [CrossRef]

20. Alonso-Gómez, A.R.; Lapidus, G.T. Inhibition of lead solubilization during the leaching of gold and silver in ammoniacal thiosulfate solutions (effect of phosphate addition). Hydrometallurgy 2009, 99, 89-96. [CrossRef]

21. Ayata, S.; Yildiran, H. Optimization of extraction of silver from silver sulphide concentrates by thiosulphate leaching. Miner. Eng. 2005, 18, 898-900. [CrossRef]

22. Feng, D.; Van Deventer, J.S.J. Leaching behaviour of sulphides in ammoniacal thiosulphate systems. Hydrometallurgy 2002, 63, 189-200. [CrossRef]

23. Xu, B.; Yang, Y.; Li, Q.; Jiang, T.; Zhang, X.; Li, G. Effect of common associated sulfide minerals on thiosulfate leaching of gold and the role of humic acid additive. Hydrometallurgy 2017, 171, 44-52. [CrossRef]

24. Molleman, E.; Dreisinger, D. The treatment of copper-gold ores by ammonium thiosulfate leaching. Hydrometallurgy 2002, 66, 1-21. [CrossRef]

25. Fleming, C.A.; Mezei, A.; Bourricaudy, E.; Canizares, M.; Ashbury, M. Factors influencing the rate of gold cyanide leaching and adsorption on activated carbon, and their impact on the design of CIL and CIP circuits. Miner. Eng. 2011, 24, 484-494. [CrossRef]

26. Navarro, P.; Vargas, C.; Villarroel, A.; Alguacil, F.J. On the use of ammoniacal/ammonium thiosulphate for gold extraction from a concentrate. Hydrometallurgy 2002, 65, 37-42. [CrossRef]

27. Tripathi, A.; Kumar, M.; Sau, D.C.; Agrawal, A.; Chakravarty, S.; Mankhand, T.R. Leaching of Gold from the Waste Mobile Phone Printed Circuit Boards (PCBs) with Ammonium Thiosulphate. IJMEE 2012, 1, 17-21. [CrossRef]

(C) 2020 by the authors. Licensee MDPI, Basel, Switzerland. This article is an open access article distributed under the terms and conditions of the Creative Commons Attribution (CC BY) license (http://creativecommons.org/licenses/by/4.0/). 